\title{
G-quadruplex based impedimetric 2-hydroxyfluorene biosensor using hemin as a peroxidase enzyme mimic
}

\author{
Gang Liang ${ }^{1,2} \cdot$ Xinhui Liu ${ }^{1}$
}

Received: 2 March 2015 / Accepted: 7 July 2015 /Published online: 17 July 2015

(C) Springer-Verlag Wien 2015

\begin{abstract}
We describe a sensitive and selective biosensor for the environmental metabolite 2-hydroxyfluorene (2-HOFlu). It is based on electrochemical impedance spectroscopy and was obtained by assembling a thiolated single-stranded DNA on a gold electrode via S-Au covalent bonding. It is then transformed to a $\mathrm{K}^{+}$-stabilized G-quadruplex-hemin complex which exhibits peroxidase-like activity to catalyze the oxidation of 2$\mathrm{HOFlu}$ by $\mathrm{H}_{2} \mathrm{O}_{2}$. This results in the formation of insoluble products that are precipitated on the gold electrode. As a result, the charge transfer resistance $\left(R_{\mathrm{CT}}\right)$ between the solution and the electrode surface is strongly increased within $10 \mathrm{~min}$ as demonstrated by using the ferro/ferricyanide system as a redox probe. The difference in the charge transfer resistances $\left(\Delta R_{\mathrm{CT}}\right)$ before and after incubation of the DNA film with 2-HOFlu and $\mathrm{H}_{2} \mathrm{O}_{2}$ serves as the signal for the quantitation of 2-HOFlu with a 1.2. $\mathrm{nM}$ detection limit in water of $\mathrm{pH}$ 7.4. The assay is highly selective over other selected fluorene derivatives. It was exploited to determine 2-HOFlu in spiked lake water samples where it displayed a detection limit of $3.6 \mathrm{nM}$. Conceivably,
\end{abstract}

Electronic supplementary material The online version of this article (doi:10.1007/s00604-015-1565-x) contains supplementary material, which is available to authorized users.

Xinhui Liu

xhliu@bnu.edu.cn

1 State Key Laboratory of Water Environment Simulation, School of Environment, Beijing Normal University, Beijing 100875, People's Republic of China

2 State Key Laboratory of Environmental Chemistry and Ecotoxicology, Research Center for Eco-Environmental Sciences, Chinese Academy of Sciences, Beijing 100085, People's Republic of China this method has a wide scope in that it may be applied to other analytes for which respective G-quadruplexes are available.

Keywords 2-Hydroxyfluorene · Fluorene metabolite . G-quadruplex · Biosensor · Electrochemical impedance spectroscopy $\cdot$ Charge transfer resistance

\section{Introduction}

Fluorene is a ubiquitously persistent environmental contaminant with high mutagenicity, teratogenicity and carcinogenicity [1,2], and it has been listed in the priority pollutants of the United States Environmental Protection Agency (US EPA). In environment, the main source of fluorene may come from production and use of fluorene as it is an important chemical material, which has been widely used as raw material of some pharmaceuticals (such as analgesic, sedative, anticonvulsant medication and anti hypertension medication), insecticide, herbicide, dyes, organic glass and accessory ingredients etc. [3], which is also the main pathway that the human body exposed to fluorene. Fluorene is metabolized in the human body and biodegraded by microbial consortia in the environment [4-6], and the major metabolite is 2-hydroxyfluorene (2HOFlu) [7], which also has metabolism-dependent cytotoxicity due to the bioactivation of 2-HOFlu. In addition, it has been confirmed that the exposure to fluorene was correlated with the corresponding metabolite of 2-HOFlu in human body [8]. Thus, 2-HOFlu has been considered as a biological marker to evaluate fluorene exposure levels [7], which can provide evidence for environmental health risk warnings, and occupational safety evaluation. Therefore, it is of significance to develop efficient assays for the determination of 2-HOFlu.

Commonly, the traditional methods applied for the quantification of 2-HOFlu in the laboratory are high-performance 
liquid chromatography (HPLC) systems with fluorescence detection [7, 8], liquid chromatography-mass spectrometry (LCMS) [9] and gas chromatography-mass spectrometry (GCMS) [10]. However, there are still some disadvantages, such as time-consuming pretreatment of the sample prior to chromatography analysis $[11,12]$. What's more, the expensive equipment, highly qualified technicians and a laboratory environment also limit the scope of their applications in field monitoring [13]. Under this situation, an achievement of sensitive, simple and economical approach for the detection of 2HOFlu is highly imperative. In contrast, electrochemical technique is an interesting and convenient alternative that has allowed one to increase the sensitivity and selectivity, simplify the detection process [14], and is ease of miniaturization [15]. Electrochemical DNA sensors are of particular interest and have been widely employed for the task of on-site detection contaminations for environmental monitoring [16-19], analysis of food, point-of-care diagnostics, fast detection of bioterrorism agents [20] as well as many other important applications due to its convenience, high selectivity and sensitivity. Especially, electrochemical impedance spectroscopy (EIS) has been proven to be a most powerful and sensitive tool for probing the features of surface-modified electrodes [21]. And EIS biosensors $\left(\left[\mathrm{Fe}(\mathrm{CN})_{6}\right]^{3-/ 4-}\right.$ as redox probe couple) possess unique advantages, such as the ability to separate the surface binding events from the solution impedance, ease of signal quantification, less damage to the biological interactions being measured, and most importantly, label-free on the DNA strand [22-24]. However, to the best of our knowledge, little efforts have been given to the development of biosensors for exploring the 2-HOFlu, and no fluorescent, colorimetric and electrochemical DNA sensors have been reported for 2-HOFlu detection. So developing EIS DNA sensor with high specificity, sensitivity is still of a great challenge.

The catalytic DNA is a single strand guanine-rich (Grich) deoxyribonucleic acid that upon binding with hemin in a G-quadruplex structure reveals peroxidase-like activity [25]. Such complexes have extensively been exploited in medicine, biology and material sciences owing to the advantages of thermal stability, simpler preparation and purification, low production cost and less nonspecific adsorption over conventional protein enzymes [26-29]. To warrant catalytic activity, the Grich DNA has to adopt a G-quadruplex structure stabilized by cations (such as $\mathrm{K}^{+}$), which then bind hemin to form a $\mathrm{K}^{+}$-stabilized G-quadruplex/hemin complex (DNAzyme) [27]. The DNAzyme catalyzes the redox reaction between the target molecules and hydrogen peroxide, producing oxidized products [30]. In addition, it has been reported that DNAzyme catalyzes the $\mathrm{H}_{2} \mathrm{O}_{2}$ mediated oxidation of some substrates (such as chloronaphthol), forming an insoluble precipitation layer on the electrode surface $[31,32]$. However, with DNA/
DNAzyme as a sensing probe, electrochemical detection of 2-HOFlu has not been reported. Therefore, the G-rich DNA modified films were prepared with the aim of detecting 2-HOFlu based on the DNAzyme catalytic oxidation of 2-HOFlu.

In the present study, an efficient and cost-effective assay for the in situ amplification determination of 2-HOFlu was reported based on the DNAzyme sensor by electrochemical impedance spectroscopy (EIS). Simply, a G-rich DNA was immobilized on the gold electrodes, and then transformed into $\mathrm{G}$-quadruplex in the presence of $\mathrm{K}^{+}$. The formed $\mathrm{K}^{+}$-stabilized G-quadruplex acted as DNAzyme (with hemin as cofactor) to catalyze $\mathrm{H}_{2} \mathrm{O}_{2}$-mediated oxidation of 2-HOFlu, producing insoluble oxidative product precipitated on the DNA films. The mechanism was characterized by UV-vis spectroscopy, fluorescence spectra, differential pulse voltammetry (DPV) and electrochemical impedance spectroscopy (EIS). Depending on the difference of charge transfer resistance change $\left(\Delta R_{\mathrm{CT}}\right)$ before and after reaction with 2-HOFlu, 2-HOFlu can be sensitively and selectively detected with a detection limit of $1.2 \mathrm{nM}$ in Tris- $\mathrm{NaClO}_{4}$ buffer solution. Finally, the DNA sensor was also challenged in natural lake water sample with a detection limit of $3.6 \mathrm{nM}$.

\section{Material and methods}

\section{Materials}

$\mathrm{K}_{3}\left[\mathrm{Fe}(\mathrm{CN})_{6}\right], \mathrm{K}_{4}\left[\mathrm{Fe}(\mathrm{CN})_{6}\right], \mathrm{NaClO}_{4}, \mathrm{KClO}_{4}, \operatorname{ABTS}\left(2,2^{\prime}-\right.$ azino-bis(3-ethylbenzothiazoline)-6-sulfonate), methanol, $\mathrm{H}_{2} \mathrm{O}_{2}$, DMSO (dimethyl sulfoxide), hemin, $\mathrm{HClO}_{4}$, Tris [tris-(hydroxymethyl)-aminomethane], 2-hydroxyfluorene (2-HOFlu), 9-hydroxyfluorene (9-HOFlu), 9-fluorenone and fluorene were purchased from Sigma-Aldrich (http:// www.sigmaaldrich.com/china-mainland.html) and used without further purification. The gold electrodes, 99. $99 \%(w / w)$ polycrystalline with a diameter of $1 \mathrm{~mm}$, were obtained from Aida Instrument Inc. in Tianjin (China) (http://www.tjaida.cn). Lake water sample was collected from Baiyangdian Lake in Hebei province (China) and filtered with the $0.45 \mu \mathrm{m}$ fiber membrane prior to use. The stock solutions of 2-HOFlu, 9-HOFlu, 9-fluorenone and fluorene were first prepared with methanol and stored at $4{ }^{\circ} \mathrm{C}$ in the dark, then diluted to different concentrations with Tris- $\mathrm{HClO}_{4}$ buffer $(20 \mathrm{mM}, \mathrm{pH}=$ 7.4) until used for electrochemical experiment. The stock solution of hemin was prepared with DMSO and kept at $20{ }^{\circ} \mathrm{C}$ in the refrigerator. The stock solution of $10 \mu \mathrm{M}$ thiolated DNA was prepared in Tris- $\mathrm{HClO}_{4}$ buffer $(20 \mathrm{mM}, \mathrm{pH}=7.4)$ and then heated at $80{ }^{\circ} \mathrm{C}$ for $5 \mathrm{~min}$ to remove DNA aggregates and to dissociate any intermolecular interaction, obtaining uniform single-standed DNA 
solution and gradually cooled to room temperature prior to use. All other solutions were prepared with Milli-Q water (18.2 $\mathrm{M} \Omega \mathrm{cm}$ resistivity) from a Millipore Milli-Q system (Thermo Scientific EASYpure II).

The following DNA sequences: thiolated DNA (1)/(2) with poly-(T) tail at the 5'-end were purchased from Shanghai Sangon Biological Engineering Technology \& Service Co. Ltd (http://www.sangon.com). The DNA (2) contains the Grich hemin-binding aptamer named PW 17 (the underlined bold region).

\section{5'-HO- $\left(\mathrm{CH}_{2}\right)_{6}$-S-S- $\left(\mathrm{CH}_{2}\right)_{6}$-TTTTTTTTT-ATGAC- ATTG-AAATC-ATA-3' (1) 5'-HO- $\left(\mathrm{CH}_{2}\right)_{6}$-S-S- $\left(\mathrm{CH}_{2}\right)_{6}$-TTTTTTTTT-GGGTA- GGGC-GGGTT-GGG-3' (2)}

\section{Monolayer preparation}

The gold electrodes were cleaned prior to DNA modification as reported before [19]. Briefly, the gold electrodes were first mechanically polished on a microcloth (Buehler) with Gamma alumina $(0.05 \mu \mathrm{m})$ slurries, followed by successive sonication in ethanol and Milli-Q water for $5 \mathrm{~min}$. Then, the electrodes were electrochemically cleaned in $1 \mathrm{~mol} \mathrm{~L}^{-1} \mathrm{H}_{2} \mathrm{SO}_{4}$ by cyclic voltammetry $(\mathrm{CV})(0-1.5 \mathrm{~V}$ vs $\mathrm{Ag} / \mathrm{AgCl}$ ) cycling to remove any remaining surface impurities. After thoroughly rinsed with Milli-Q water, the gold electrodes were blown-dry with a nitrogen gun, and ready for DNA modification. The thiolated DNA solution was diluted in $20 \mathrm{mM}$ Tris- $\mathrm{HClO}_{4}$ buffer $(\mathrm{pH}=7.4)$ with a final concentration of $1 \mu \mathrm{M}$. Then, the DNA films on the gold electrodes were prepared by incubating the freshly cleaned gold electrodes in the prepared DNA solutions, followed by backfilling potential pinholes and defects by soaking the DNA films in $1 \mathrm{mM} 6$ mercaptohexanol for $1 \mathrm{~h}$. After rinsing with $20 \mathrm{mM}$ Tris- $\mathrm{HClO}_{4}$ buffer, the electrodes were then sequentially incubated in the Tris- $\mathrm{HClO}_{4}$ buffer $\left(10 \mathrm{mM} \mathrm{K} \mathrm{K}^{+}, \mathrm{pH}=\right.$ 7.4) for $1 \mathrm{~h}$, hemin/Tris- $\mathrm{HClO}_{4}$ solution $(1 \mu \mathrm{M}$ hemin, $10 \mathrm{mM} \mathrm{K}^{+}, \mathrm{pH}=7.4$ ) for $1 \mathrm{~h}$ and different concentration of 2-HOFlu/Tris- $\mathrm{HClO}_{4}$ solution $\left(1 \mathrm{mM} \mathrm{H} \mathrm{H}_{2} \mathrm{O}_{2}, \mathrm{pH}=7.4\right)$ for $10 \mathrm{~min}$. All experiments were conducted at $25{ }^{\circ} \mathrm{C}$ in Tris- $\mathrm{HClO}_{4}$ buffer solution $(20 \mathrm{mM}, \mathrm{pH}=7.4)$.

\section{Electrochemical measurements}

Electrochemical impedance spectroscopy (EIS) was carried out to measure the modification process of the electrode surface. Impedance spectra were measured using a potentiostat frequency analyzer (EG\&G 2273). The ac voltage amplitude was $5 \mathrm{mV}$, and the voltage frequencies used for EIS measurements ranged from $100 \mathrm{kHz}$ to $100 \mathrm{mHz}$. The applied potential was $250 \mathrm{mV}$ vs. $\mathrm{Ag} / \mathrm{AgCl}$ (formal potential of the redox probe $\left[\mathrm{Fe}(\mathrm{CN})_{6}\right]^{3-4-}$ in the Tris- $\mathrm{HClO}_{4}$ buffer solution). As reported before [19], a conventional three-electrode system was used, and all the measurements were carried out in an enclosed and grounded Faraday cage. The reference electrode was constructed by sealing an $\mathrm{Ag} / \mathrm{AgCl}$ wire into a glass tube with a solution of saturated $\mathrm{KCl}$ that was capped with a Vycor tip. The counter electrode was a platinum wire. All measurements were repeated for a minimum of three times with separate electrode to obtain the statistically meaningful result.

\section{UV-vis spectroscopic analysis}

Typically, the peroxidase-mimicking DNAzyme activity assay was carried out in the ABTS- $\mathrm{H}_{2} \mathrm{O}_{2}$ reaction system. Firstly, the $\mathrm{K}^{+}$-stabilized G-quadruplex complex was prepared by was diluting DNA strand (2) in $\mathrm{Tris}-\mathrm{HClO}_{4}$ buffer solution (20 mM, pH=7.4) containing $10 \mathrm{mM} \mathrm{K}^{+}$. Then, hemin was added after $1 \mathrm{~h}$, obtaining the hemin $/ \mathrm{K}^{+}$-stabilized Gquadruplex complex (DNAzyme (2)). The same procedure was also done for the arbitrary DNA strand (1), obtaining non-DNAzyme (1). All experiments were conducted at room temperature.

For the DNAzyme activity assay experiment, the peroxidation reaction was initiated by the addition of $10 \mu \mathrm{L}$ of $\mathrm{H}_{2} \mathrm{O}_{2}$ (200 mM) to $790 \mu \mathrm{L}$ of Tris- $\mathrm{HClO}_{4}$ buffer solution $(20 \mathrm{mM}$, $\mathrm{pH}=7.4$ ) containing $2 \mathrm{mM}$ ABTS and $0.05 \mu \mathrm{M}$ nonDNAzyme (1)/DNAzyme (2). The absorption spectra of the reaction mixture were then recorded within 4 min with a Cazy 50 Scan UV-vis Spectrophotometer with the wavelength $(\lambda)$ ranged from 500 to $390 \mathrm{~nm}$ and scan rate of $600 \mathrm{~nm} \mathrm{~min}^{-1}$.

\section{Fluorescence spectrometry measurement}

The fluorescence measurements were performed on a Cary Eclipse fluorescence spectrophotometer (VARIAN, USA) with the following settings: $\lambda_{\mathrm{ex}}=252 \mathrm{~nm}, \lambda_{\mathrm{em}}=332 \mathrm{~nm}$ for $2-\mathrm{HOFlu}, 5 \mathrm{~nm}$ slit and PMT detector voltage $=650 \mathrm{~V}$. Briefly, $5 \mu \mathrm{M}$ 2-HOFlu Tris- $\mathrm{HClO}_{4}$ solution $(20 \mathrm{mM}, \mathrm{pH}=7.4)$ containing $1 \mathrm{mM} \mathrm{H}_{2} \mathrm{O}_{2}$ in the absence and presence of $50 \mathrm{nM}$ DNAzyme (2) were respectively achieved by stirring for $10 \mathrm{~min}$ at room temperature. Then the corresponding fluorescence emission spectra were measured.

\section{Safety considerations}

The fluorene and its derivatives are potentially carcinogenic agents. MSDS information for these chemicals should be consulted, and precautions should be taken for using them (i.e., wearing gloves and mask). All experiments should be done in the laboratory fume hood. 


\section{Results and discussion}

\section{Optimization of pH}

$\mathrm{K}^{+}$-stabilized G-quadruplex/hemin complex (DNAzyme) is able to catalyze the $\mathrm{H}_{2} \mathrm{O}_{2}$-mediated oxidation of ABTS, producing the free-radical cation $\mathrm{ABTS}^{++}$, showing a maximal absorption at $422 \mathrm{~nm}$ [29]. Therefore, the change in the absorption signal at $422 \mathrm{~nm}$ can be employed to monitor the formation and the activity of the DNAzyme. Actually, the activity of the DNAzyme is very important for the feasible application of the DNA sensor to detect 2-HOFlu. Therefore, the DNAzyme activity was first explored by the colorimetric assay with the $\mathrm{pH}$ of the Tris- $\mathrm{HClO}_{4}$ buffer solution $(20 \mathrm{mM})$ ranged from 4 to 10 as shown in Fig. S1 (Electronic Supplementary Material). The results showed the DNAzyme exhibits lower catalytic activity when the buffer solution is acidic $(<6)$ or alkaline $(>8.5)$, and the optimum $\mathrm{pH}$ for the DNAzyme catalytic activity was about 7.4 , suggesting the catalytic activity of the DNAzyme was $\mathrm{pH}$ dependent. Therefore, the $\mathrm{pH}$ of the Tris- $\mathrm{HClO}_{4}$ buffer was adjusted to 7.4 prior to 2 -HOFlu detection.

\section{Electrochemical detection of 2-hydroxyFluorene}

As reported before [19], the DNA (2) films were prepared by incubating the freshly cleaned gold electrodes in $1 \mu \mathrm{M}$ DNA (2) solution, followed by backfilling potential pinholes and defects through soaking the DNA (2) films in $1 \mathrm{mM} 6$ mercaptohexanol. Then the DNA (2) strands self-assembled on the gold electrodes surface were transformed into $\mathrm{K}^{+}$stabilized G-quadruplex/hemin complex (DNAzyme). Subsequently, the formed DNAzyme on the gold electrodes was applied to catalyze $\mathrm{H}_{2} \mathrm{O}_{2}$-mediated oxidation of 2HOFlu, immersing the electrodes in $10 \mu \mathrm{M}$ 2-HOFlu Tris$\mathrm{HClO}_{4}$ solution $(20 \mathrm{mM}, \mathrm{pH}=7.4)$ containing $1 \mathrm{mM} \mathrm{H}_{2} \mathrm{O}_{2}$. Electrochemical impedance spectroscopy (EIS) was carried out to characterize the 2-HOFlu oxidation on the DNAzyme film and the representative Nyquist plots before and after incubating with $10 \mu \mathrm{M}$ 2-HOFlu were shown in Fig. 1 . The impedance spectra were analyzed with the modified Randles' equivalent circuit (inset of Fig. 1) [33], and the fitting results were listed in Table 1.

The solution resistance, $R_{\mathrm{s}}$, is the resistance between the reference electrode and the films of DNA (2) on the gold electrodes, which ranged from 6.8 to $7.5 \Omega \cdot \mathrm{cm}^{2}$. $C_{\text {film }}$ accounts for the capacitance of the DNA (2) films on the gold electrodes. As shown in Fig. 2, $C_{\text {film }}$ was slightly decreased after immersed in $10 \mu \mathrm{M} 2$-HOFlu solution (containing $1 \mathrm{mM}$ $\mathrm{H}_{2} \mathrm{O}_{2}$ ), revealing that the oxidation interaction on the DNA (2) film might result in an increase in the film thickness that led to a decreased dielectric constant [31]. The combination of $R_{\mathrm{x}}$ and the constant phase element (CPE) accounts for the

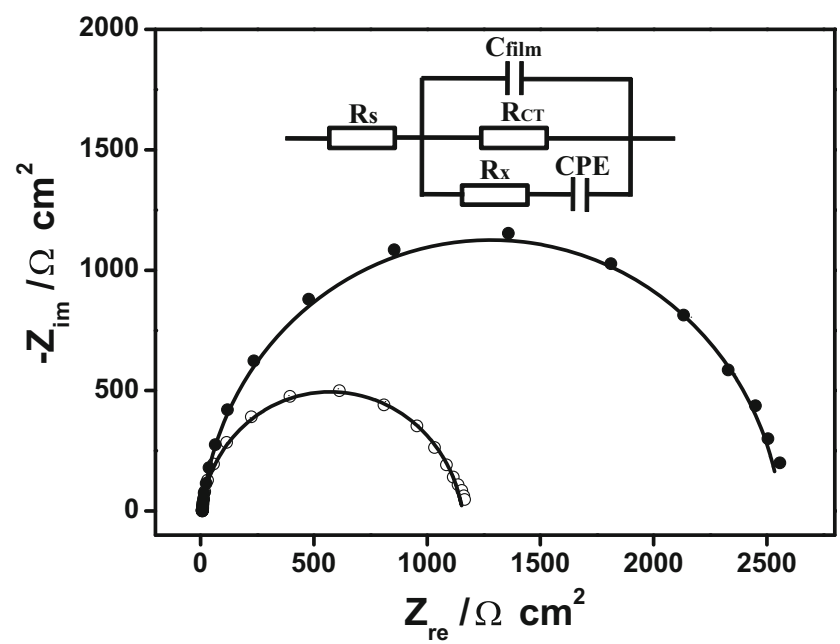

Fig. 1 Representative Nyquist plots ( $-Z_{\text {im }}$ vs. $Z_{\text {re }}$ ) for DNA (2) films (white circle) before and after interaction with $10 \mu \mathrm{M} 2$-HOFlu for $10 \mathrm{~min}$ (Containing $1 \mathrm{mM} \mathrm{H}_{2} \mathrm{O}_{2}$ ) (black circle). Measured data were shown as symbols with calculated fit to the equivalent circuit as solid lines. Inset: the measured data were fit to the equivalent circuit; $R_{\mathrm{s}}$, solution resistance; $R_{\mathrm{CT}}$, charge-transfer resistance; $C_{\text {film }}$, capacitance of the DNA (2) films; $R_{\mathrm{x}}$ and $\mathrm{CPE}$, resistance and nonlinear capacitor accounting for 6mercaptohexanol film

behavior of the 6-mercaptohexanol groups on the electrode surfaces [34]. Mass transport is not a major contributor because of the absence of Warburg impedance as shown in Fig. 1.

The most important parameter is the charge-transfer resistance, $R_{\mathrm{CT}}$, which is the result of the resistance to charge transfer between the solution-based redox probe $\left[\mathrm{Fe}(\mathrm{CN})_{6}\right]^{3-1}$ 4- and the electrode surface. As shown in Table 1, after incubating the DNA (2) films with $10 \mu \mathrm{M}$ 2-HOFlu solution (containing $1 \mathrm{mM} \mathrm{H}_{2} \mathrm{O}_{2}$ ) for $10 \mathrm{~min}$, the $R_{\mathrm{CT}}$ increased from $1150(30) \Omega \cdot \mathrm{cm}^{2}\left(R_{\mathrm{CT} \text { (before) }}\right)$ to $2555(53) \Omega \cdot \mathrm{cm}^{2}\left(R_{\mathrm{CT}(\text { after })}\right)$ and the $R_{\mathrm{CT}}$ difference $\left(\Delta R_{\mathrm{CT}}=R_{\mathrm{CT} \text { (after) }}-R_{\mathrm{CT} \text { (before) }}\right)$ was about $1405(57) \Omega \cdot \mathrm{cm}^{2}$. This can be explained by the $\mathrm{H}_{2} \mathrm{O}_{2}$-mediated oxidation of 2-HOFlu catalyzed by the transformed DNAzyme films from the G-DNA (2). An insoluble product is formed that hinders electron transfer [31]. Therefore, the $\Delta R_{\mathrm{CT}}$ was a very significant parameter to be applied for the detection of 2-HOFlu.

\section{Demonstration of the mechanism}

As for the mechanism, the $\mathrm{K}^{+}$-stabilized G-quadruplex/hemin complex (DNAzyme) is critical. For comparison, the G-rich DNA (2) and the arbitrary DNA (1) were selected to catalyze ABTS- $\mathrm{H}_{2} \mathrm{O}_{2}$ system in the presence of $\mathrm{K}^{+}$and/or hemin as the DNAzyme is able to catalyze the $\mathrm{H}_{2} \mathrm{O}_{2}$-mediated oxidation of ABTS, producing the free-radical cation $\mathrm{ABTS}^{\circ+}$, showing a maximal absorption at $422 \mathrm{~nm}$ [29]. The results were shown in Fig. 2a. No absorption peak was observed in the presence of ABTS (curve b), the sensing system showed a very low 
Table 1 Equivalent circuit element values for DNA (2) Films before and after Incubating with $10 \mu \mathrm{M}$ 2-HOFlu

\begin{tabular}{llllllll}
\hline \multicolumn{7}{c}{ Circuit elements } & \\
\cline { 2 - 7 } & $R_{\mathrm{s}}\left(\Omega \cdot \mathrm{cm}^{2}\right)$ & $C_{\text {film }}\left(\mu \mathrm{F} \cdot \mathrm{cm}^{-2}\right)$ & $R_{\mathrm{CT}}\left(\Omega \cdot \mathrm{cm}^{2}\right)$ & $R_{\mathrm{x}}\left(\Omega \cdot \mathrm{cm}^{2}\right)$ & $\mathrm{CPE}\left(\mu \mathrm{F} \cdot \mathrm{cm}^{-2}\right)$ & $n$ & $\Delta R_{\mathrm{CT}}\left(\Omega \cdot \mathrm{cm}^{2}\right)$ \\
\hline DNA (2) & $6.8(0.1)$ & $11.7(0.3)$ & $1150(30)$ & $9.9(0.5)$ & $15.2(0.7)$ & $0.8(0.2)$ & 0 \\
+2-HOFlu & $7.5(0.3)$ & $11.0(0.2)$ & $2555(53)$ & $15.9(1.0)$ & $15.9(0.5)$ & $0.9(0.3)$ & $1405(57)$ \\
\hline
\end{tabular}

The values in parentheses represent the standard deviations from at least three electrode measurements

absorption signal at $422 \mathrm{~nm}$; and a slightly higher absorption signal appeared when hemin was added (curve d), which was due to the weak catalytic activity of hemin to the $\mathrm{H}_{2} \mathrm{O}_{2}$. However, no catalytic activity was observed when the arbitrary

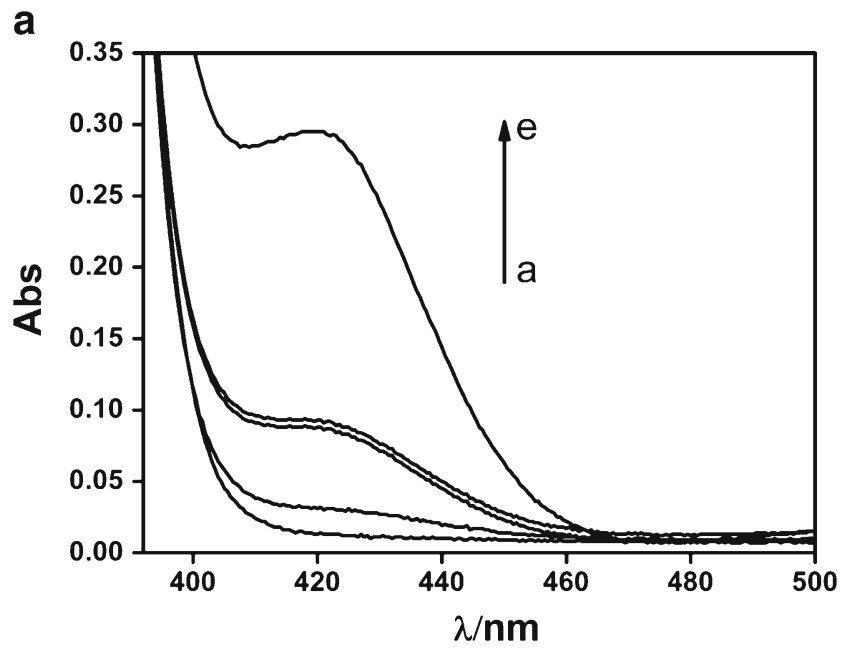

b

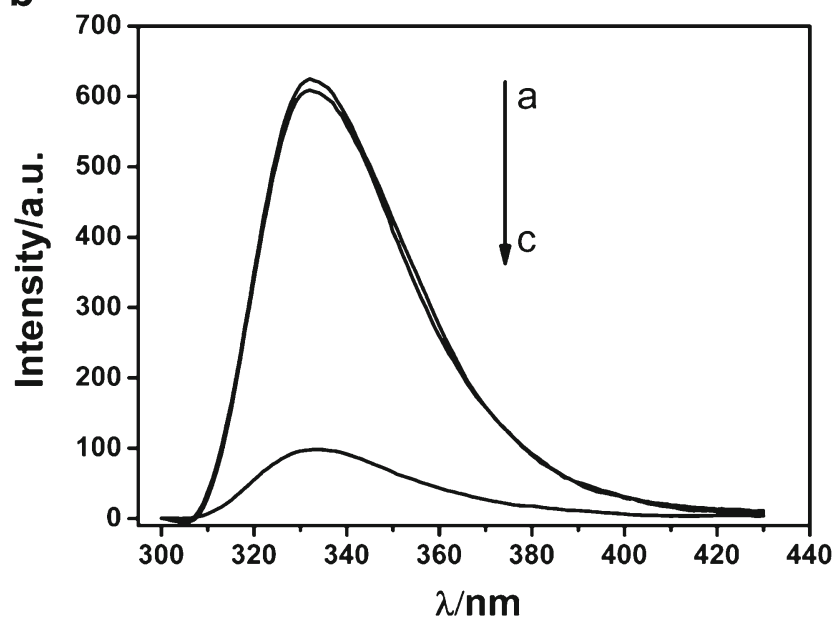

Fig. 2 a The absorption spectra in Tris- $\mathrm{HClO}_{4}$ buffer solution $(20 \mathrm{mM}$, $\mathrm{pH}=7.4)$ : (a) buffer solution; (b) ABTS; (c) DNA(1)+hemin+ABTS+ $\mathrm{H}_{2} \mathrm{O}_{2} ;(d)$ hemin + ABTS $+\mathrm{H}_{2} \mathrm{O}_{2} ;($ e $)$ DNA(2)+hemin + ABTS $+\mathrm{H}_{2} \mathrm{O}_{2}$. (DNA: $0.05 \mu \mathrm{M}$; hemin: $0.05 \mu \mathrm{M}$; ABTS: $2 \mu \mathrm{m}$; $\mathrm{K}^{+}: 10 \mathrm{mM} ; \mathrm{H}_{2} \mathrm{O}_{2}$ : $2.5 \mathrm{mM})$; b Fluorescence spectra of 2-HOFlu $(5 \mu \mathrm{M})$ in $\mathrm{Tris}-\mathrm{HClO}_{4}$ buffer solution $(20 \mathrm{mM}, \mathrm{pH}=7.4)$ containing $10 \mathrm{mM} \mathrm{K}^{+}$in the absence and presence of $50 \mathrm{nM}$ DNAzyme (2) and $1 \mathrm{mM} \mathrm{H}_{2} \mathrm{O}_{2}$ for $10 \mathrm{~min}$ at $25^{\circ} \mathrm{C}$. (a: $5 \mu \mathrm{M}$ 2-HOFlu; $b$ : $5 \mu \mathrm{M}$ 2-HOFlu $+1 \mathrm{mM} \mathrm{H}_{2} \mathrm{O}_{2} ; c: 5 \mu \mathrm{M} 2-$ $\mathrm{HOFlu}+50$ nM DNAzyme (2) $+1 \mathrm{mM} \mathrm{H}_{2} \mathrm{O}_{2}$ )
non-DNAzyme DNA (1) was used (curve c). As expected, the absorption intensity greatly increased in the presence of DNAzyme (2) (curve e), which was attributed to the formed DNAzyme (2) that significantly enhanced the catalytic activity, producing much more free-radical cation $\mathrm{ABTS}^{*+}$ [35]. The results demonstrated that in the presence of $\mathrm{K}^{+}$and hemin, the G-rich DNA (2) is transformed into a $\mathrm{K}^{+}$-stabilized G-quadruplex/hemin and exhibit catalytic activity.

Next, the $\mathrm{K}^{+}$-stabilized G-quadruplex/hemin complex (DNAzyme (2) transformed from single strand DNA (2) was applied to catalyze $\mathrm{H}_{2} \mathrm{O}_{2}$-mediated oxidation of 2-HOFlu, which was characterized through the fluorescence spectrome-

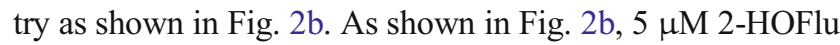
exhibited strong fluorescence at $332 \mathrm{~nm}$ with an excitation at $253 \mathrm{~nm}$ (curve a). Upon addition of $1 \mathrm{mM} \mathrm{H}_{2} \mathrm{O}_{2}$ for $10 \mathrm{~min}$, the intensity of the fluorescence was slightly decreased (curve b). Alternatively, upon adding $1 \mathrm{mM} \mathrm{H}_{2} \mathrm{O}_{2}$ and $50 \mathrm{nM}$ DNAzyme (2) (curve c), the fluorescence intensity of 2HOFlu was sharply decreased (about $84.1 \%$ of the fluorescence intensity lost), indicating that 2-HOFlu was quickly oxidized by $\mathrm{H}_{2} \mathrm{O}_{2}$ to its products without fluorescence at $470 \mathrm{~nm}$. The reason might be due to the destroyed structure of conjugated molecule 2-HOFlu, resulting in the fluorescence quenching. However, the positive results confirmed that the DNAzyme can significantly accelerate the $\mathrm{H}_{2} \mathrm{O}_{2}$-mediated oxidation of 2-HOFlu.

Furthermore, the formation of the $\mathrm{K}^{+}$-stabilized Gquadruplex/hemin complex (DNAzyme (2)) on the electrodes was confirmed by the differential pulse voltammetry (DPV). As shown in Fig. 3a, no reduction peak was observed for the DNA films (curve c), and a weak reduction peak of hemin appeared at $-0.315 \mathrm{~V}$ for the DNA (1) modified film after incubation in the $\mathrm{K}^{+} /$hemin solution (curve b), which is attributed to the non-specific interaction of hemin with DNA. However, a very strong peak was observed at about $-0.335 \mathrm{~V}$ after immersing the $\mathrm{K}^{+}$-stabilized G-quadruplex DNA (2) modified film in the hemin solution (curve a). This peak corresponds to the reduction of hemin that binding with the $\mathrm{K}^{+}$-stabilized Gquadruplex [36], and also indicated the formation of hemin/Gquadruplex complex on the electrode [37].

Subsequently, the $\Delta R_{\mathrm{CT}}$ as a function of reaction time at the DNA (2) films on the gold electrodes were further explored by using an arbitrary non-DNAzyme (1) and DNAzyme (2). As 

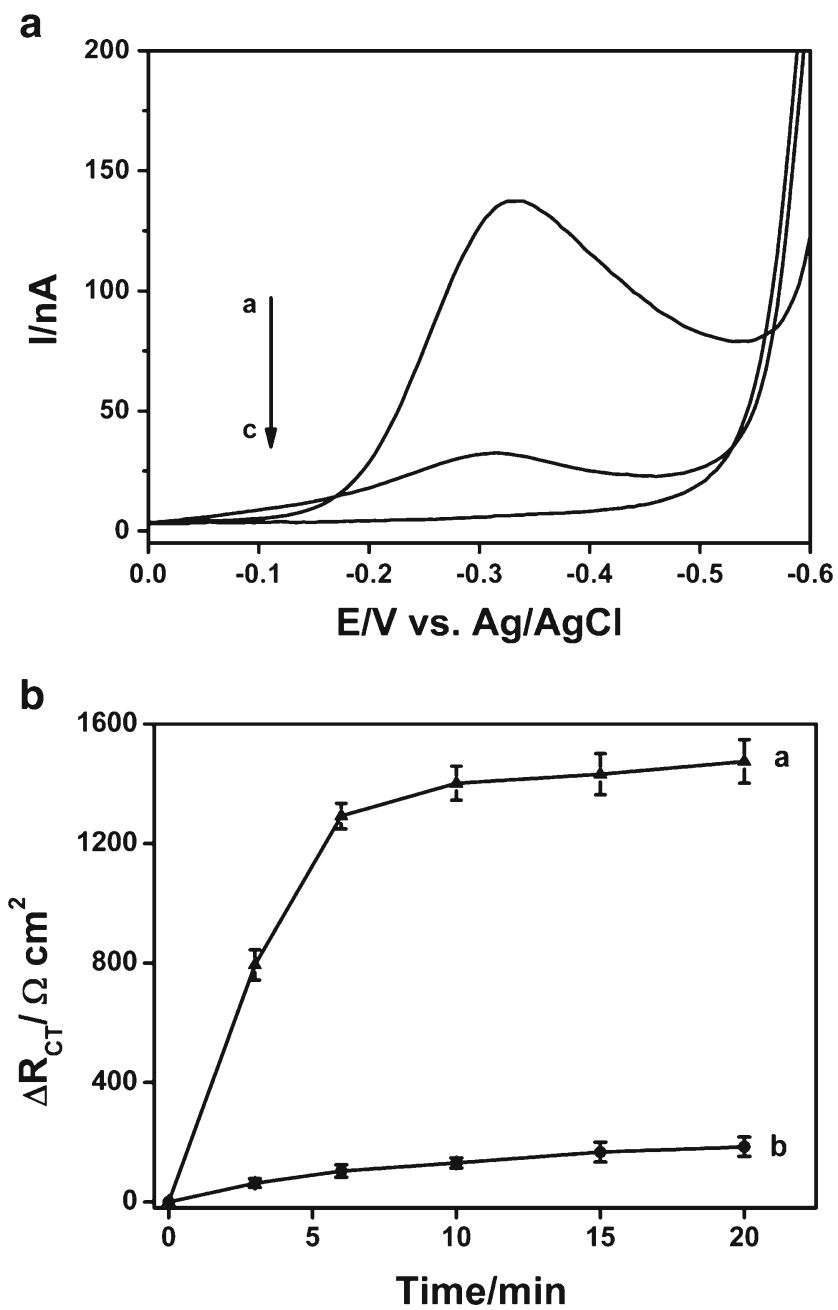

Fig. 3 a Differential pulse voltammograms of the fabricated biosensor measured in Tris-NaClO4 buffer solution ( $20 \mathrm{mM}, \mathrm{pH}=7.4)$ : (a) G-DNA (2) $+\mathrm{K}^{+}+$hemin; (b) DNA (1) $+\mathrm{K}^{+}+$hemin; (c) DNA (1) $\left(\mathrm{K}^{+} 20 \mu \mathrm{M}\right.$, hemin $2 \mu \mathrm{M})$; $\mathbf{b}$ The time-dependent $\Delta R_{\mathrm{CT}}$ changes of the DNAzyme (2) modified flims $(a)$ and non-DNAzyme DNA (1) modified films $(b)$ in the presence of $10 \mu \mathrm{M}$ of 2-HOFlu containing $1 \mathrm{mM} \mathrm{H}_{2} \mathrm{O}_{2}$ in Tris- $\mathrm{NaClO}_{4}$ buffer solution $(20 \mathrm{mM}, \mathrm{pH}=7.4)$. Error bars are derived from a minimum of three electrodes

shown in Fig. 3b., a significant $\Delta R_{\mathrm{CT}}$ change was observed when the DNAzyme (2) was utilized until no change was observed at $10 \mathrm{~min}$, while only a very small increase of $\Delta R_{\mathrm{CT}}$ for the non-DNAzyme (1) modified films, which was presumably caused by the absorbed hemin on the arbitrary DNA (1) in the pre-incubation procedure. These results were well in accordance with the UV-vis analysis and the DPV measurements. Therefore, the increased $\Delta R_{\mathrm{CT}}$ confirmed the precipitation layer on the DNA (2) films due to the effectively catalytic oxidation of 2-HOFlu by $\mathrm{H}_{2} \mathrm{O}_{2}$. In addition, the 10 min reaction time was chosen in the present study.

Based on the results discussed above, it can be concluded that: (1) the thiolated DNA (2) was modified on the gold electrodes via the strong covalent Au-S bond; (2) the immobilized single-strand DNA (2) folded into Gquadruplex structure in the presence of $\mathrm{K}^{+}$and further forming $\mathrm{K}^{+}$-stabilized G-quadruplex/hemin complex by binding with hemin; (3) the formed $\mathrm{K}^{+}$-stabilized G-quadruplex/hemin complex can effectively catalyze the $\mathrm{H}_{2} \mathrm{O}_{2}$-mediated oxidation of 2-HOFlu, producing insoluble oxidative products precipitated on the DNA films.

\section{Sensitivity and selectivity}

Based on the mechanism, single strand DNA (2) was applied as a sensing probe to immobilize on the gold electrodes for electrochemical detection of 2-HOFlu by EIS. First, the GDNA (2) was self-assembled on the gold electrodes. Then, in the presence of $\mathrm{K}^{+}$and hemin, DNA (2) transformed into $\mathrm{K}^{+}$-stabilized G-quadruplex/hemin complex on the electrodes. Next, the prepared electrodes were incubated in the solutions of 2-HOFlu (containing $1 \mathrm{mM} \mathrm{H}_{2} \mathrm{O}_{2}$ ) with the concentration ranged from $0.1 \mathrm{nM}$ to $100 \mu \mathrm{M}$. EIS was respectively recorded and analyzed with the help of the equivalent circuit shown inset of Fig. 1.

The relationship between the $\Delta R_{\mathrm{CT}}$ of the DNA (2) films and the concentrations of 2-HOFlu was shown in Fig. 4a. Upon decreasing the concentration of 2-HOFlu from $100 \mu \mathrm{M}$ to $0.1 \mathrm{nM}$, the lower concentration of 2-HOFlu was used, the less oxidative product precipitated on the DNA films. The result directly led to a decreased $\Delta R_{\mathrm{CT}}$ until no distinct change in $\Delta R_{\mathrm{CT}}$ was observed with the $1 \mathrm{nM} 2-$ HOFlu used. The inset of Fig. 4a showed the linear relationship between $\Delta R_{\mathrm{CT}}$ and the concentrations of 2-HOFlu ranged from $10^{-5}$ to $10^{-8} \mathrm{M}$, and the linear regression equation was $\mathrm{Y}$ $\left(\Delta R_{\mathrm{CT}}\right)=3271+358.7 \mathrm{lg}\left[\mathrm{C}_{2-\mathrm{HOFlu}}\right]$ with a correlation coefficient of 0.99 . The detection limit was determined to be $1.2 \mathrm{nM}$ $(\mathrm{S} / \mathrm{N}=3)$, which can be compared with that of HPLC, GC-MS and LC-MS assays as shown in Table S1.

In addition, the selectivity of the sensor was also exploited through incubating the prepared gold electrodes with other possible fluorene derivatives (such as $100 \mathrm{nM}$ 9-HOFlu, 9fluorenone and fluorene), respectively. As shown in Fig. 4b, only 2 -HOFlu can cause a considerable increase in $\Delta R_{\mathrm{CT}}$ while other selected fluorene derivatives made a small $\Delta R_{\mathrm{CT}}$. Besides, the determination of 2-HOFlu was hardly not affected by the selected fluorene derivatives in the co-existing system, which indicated that the reported DNA biosensor was specifically sensitive for 2-HOFlu detection. It should be noted that, however, why the selected fluorene derivatives performed different impedance behavior from that of 2-HOFlu? As for this question, further studies are undergoing in our laboratory. Nevertheless, such ability of the reported DNA sensor to discriminate 2-HOFlu from selected fluorene 


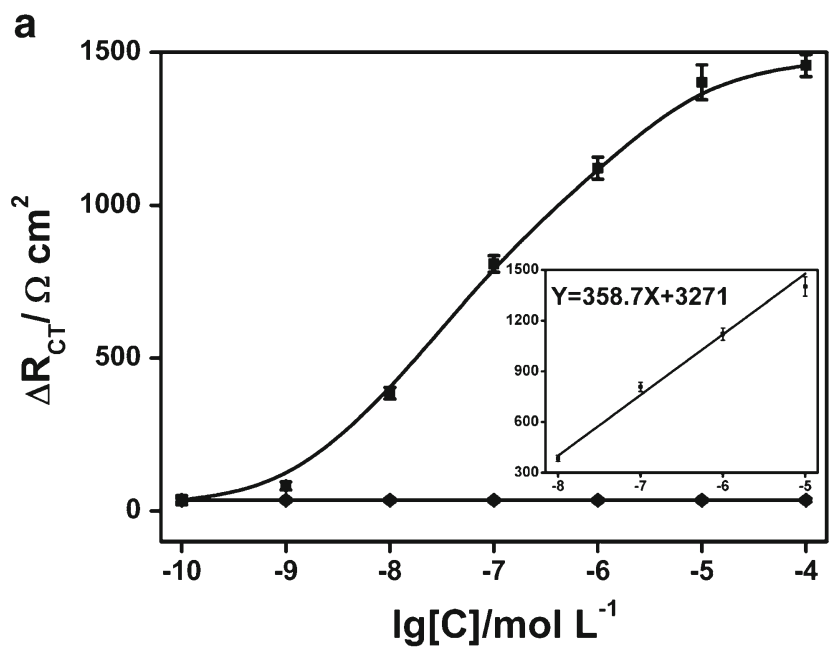

b

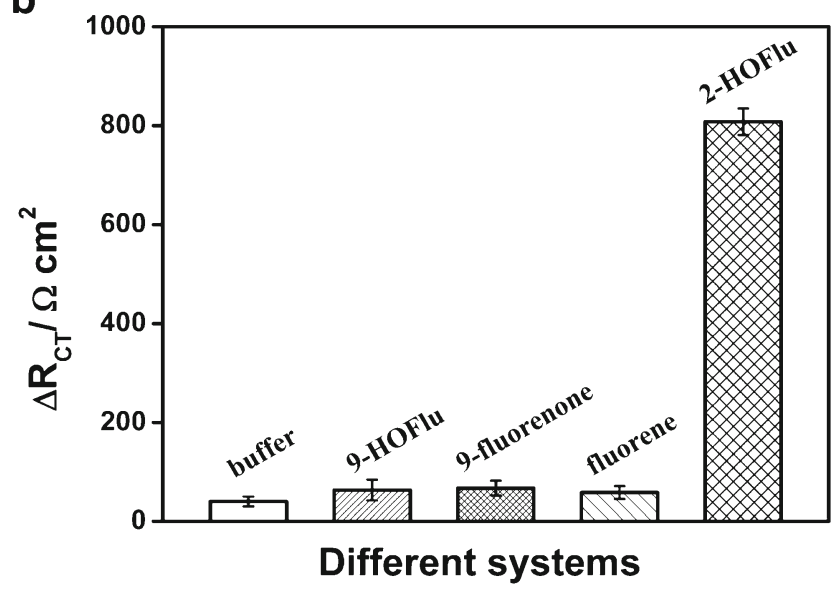

C

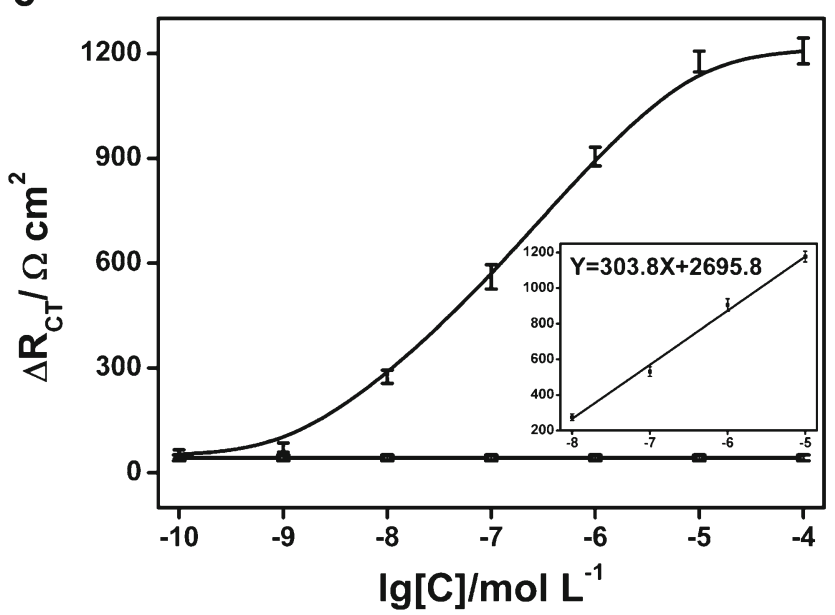

Fig. 4 Sensitivity for 2-HOFlu in Tris- $\mathrm{NaClO}_{4}$ buffer (a): relationship between $\Delta R_{\mathrm{CT}}$ and the concentrations of 2-HOFlu; Selectivity of the sensor in Tris- $\mathrm{NaClO}_{4}$ buffer for $100 \mathrm{nM}$ 2-HOFlu and other selected compounds (such as 9-hydroxyfluorene (9-HOFlu) 9-fluorenone and fluorene) (b); Sensitivity for 2-HOFlu in lake water sample (c): relationship between $\Delta R_{\mathrm{CT}}$ and the concentrations of 2-HOFlu. Error bars were derived from a minimum of three electrodes derivatives by EIS added a new and important dimension of selectivity. Furthermore, it is of great significance to investigate whether DNAzyme can play roles in the $\mathrm{H}_{2} \mathrm{O}_{2}$-mediated oxidation of other environmental pollutants, such as chlorophenols, aminophenols nitrophenols and other toxic pollutants. And it is hopeful that the peroxidase-like DNAzyme can substitute the protein enzymes for prospective future application to other protein enzymes related researches.

\section{Practical application in lake water}

Finally, the potential performance of the DNA sensor for the 2-HOFlu analysis in natural water sample was also explored. Figure $4 \mathrm{c}$ showed the relationship of the $\Delta R_{\mathrm{CT}}$ and the concentrations of 2-HOFlu in the natural lake water. As shown in Fig. 4c, after incubating the DNA sensor in the lake water containing 2-HOFlu ( $1 \mathrm{mM} \mathrm{H}_{2} \mathrm{O}_{2}$ ) with the concentrations ranged from $100 \mu \mathrm{M}$ to $0.1 \mathrm{nM}$, a continuously decreased $R_{\mathrm{CT}}$ was respectively obtained as well. The inset of Fig. $4 \mathrm{c}$ showed the linear relationship between $\Delta R_{\mathrm{CT}}$ and the concentrations of 2-HOFlu ranged from $10^{-5} \mathrm{M}$ to $10^{-8} \mathrm{M}$, and the linear regression equation was $\mathrm{Y}\left(\Delta R_{\mathrm{CT}}\right)=2695.8+303.8 \mathrm{lg}$ $\left[\mathrm{C}_{2-\mathrm{HOFlu}}\right]$ with a correlation coefficient 0.99 . The detection limit was calculated to be $3.6 \mathrm{nM}(\mathrm{S} / \mathrm{N}=3)$. The results showed that the assay exhibited excellent capacity of resisting disturbance and is efficiently applied to detect 2-HOFlu in natural water sample.

\section{Conclusions}

In this paper, we designed an in situ amplification sensing strategy to detect 2-HOFlu with high sensitivity and selectivity by electrochemical impedance spectroscopy. The G-rich DNA strand was self-assembled on the gold electrodes and transformed into $\mathrm{K}^{+}$-stabilized G-quadruplex/hemin complex in the presence of $\mathrm{K}^{+}$and hemin, which can catalyze $\mathrm{H}_{2} \mathrm{O}_{2}$ mediated oxidation of 2-HOFlu to produce insoluble products precipitated on the DNA films, causing an increased charge transfer resistance. Depending on the difference in charge transfer resistance, 2-HOFlu was sensitively and sensitively detected with the detection limit of $1.2 \mathrm{nM}$ in Tris- $\mathrm{HClO}_{4}$ buffer. Furthermore, the DNA sensor was successfully applied to detect 2-HOFlu in natural lake water sample with a detection limit of $3.6 \mathrm{nM}$. The sensing assay has the potential to be further extended to investigate the interaction with other contaminants to evaluate their environmental toxicity. And the peroxidase-like DNAzyme has a wide scope in that it may be applied to other protein enzymes related researches. 
Acknowledgments We are grateful for financial support from the National Science Foundation for Innovative Research Group (51121003) and the National Natural Science Foundation of China (21377013), Major State Basic Research Development Program (2013CB430405) and Fundamental Research Funds for the Central Universities and the China Postdoctoral Science Foundation (2014 M550854).

\section{References}

1. Ma L, Chu S, Wang X, Cheng H, Liu X, Xu X (2005) Polycyclic aromatic hydrocarbons in the surface soils from outskirts of Beijing, China. Chemosphere 58:1355

2. Yin C, Jiang X, Yang X, Bian Y, Wang F (2008) Polycyclic aromatic hydrocarbons in soils in the vicinity of Nanjing, China. Chemosphere 73:389

3. Wu H, Xue Y, You Q, Huang Q, Ou J (2009) Analysis of pyrolysis components of biomass tar by GC-MS. Chem Eng Oil Gas 38:72

4. Sepic E, Bricelj M, Leskovsek H (2003) Toxicity of fluoranthene and its biodegradation metabolites to aquatic organisms. Chemosphere 52:1125

5. Haritash AK, Kaushik CP (2009) Biodegradation aspects of polycyclic aromatic hydrocarbons (PAHs): a review. J Hazard Mater 169:1

6. Luan TG, Yu KSH, Zhong Y, Zhou HW, Lan CY, Tam NFY (2006) Study of metabolites from the degradation of polycyclic aromatic hydrocarbons (PAHs) by bacterial consortium enriched from mangrove sediments. Chemosphere 65:2289

7. Toriba A, Chetiyanukornkul T, Kizu R, Hayakawa K (2003) Quantification of 2-hydroxyfluorene in human urine by columnswitching high performance liquid chromatography with fluorescence detection. Analyst 128:605

8. Chetiyanukornkul T, Toriba A, Kizu R, Hayakawa K (2004) Urinary 2-hydroxyfluorene and 1-hydroxypyrene levels in smokers and nonsmokers in Japan and Thailand. Polycycl Aromat Compd $24: 467$

9. Kamiya M, Toriba A, Onoda Y, Kizu R, Hayakawa K (2005) Evaluation of estrogenic activities of hydroxylated polycyclic aromatic hydrocarbons in cigarette smoke condensate. Food Chem Toxicol 43:1017

10. Campo L, Rossella F, Fustinoni S (2008) Development of a gas chromatography/mass spectrometry method to quantify several urinary monohydroxy metabolites of polycyclic aromatic hydrocarbons in occupationally exposed subjects. J Chromatogr B 875:531

11. Ding YP, Liu WL, Wu QS, Wang XG (2005) Direct simultaneous determination of dihydroxybenzene isomers at C-nanotubemodified electrodes by derivative voltammetry. J Electroanal Chem 575:275

12. Zhu G, Gai P, Wu L, Zhang J, Zhang X, Chen J (2012) $\beta$ cyclodextrin-platinum nanoparticles/graphene nanohybrids: enhanced sensitivity for electrochemical detection of naphthol isomers. Chem Asian J 7:732

13. Wang Y, Wang J, Yang F, Yang X (2010) Spectrophotometric detection of lead (II) ion using unimolecular peroxidase-like deoxyribozyme. Microchim Acta 171:195

14. Drummond TG, Hill MG, Barton JK (2003) Electrochemical DNA sensors. Nat Biotechnol 21:1192

15. Wang P, Mai Z, Dai Z, Zou X (2010) Investigation of DNA methylation by direct electrocatalytic oxidation. Chem Commun 46: 7781

16. Andreescu S, Sadik OA (2004) Trends and challenges in biochemical sensors for clinical and environmental monitoring. Pure Appl Chem 76:861
17. Vestergaard M, Kerman K, Tamiya E (2007) An overview of labelfree electrochemical protein sensors. Sensors 7:3442

18. Wu LD, Lu X, Jin JB, Zhang HJ, Chen JP (2011) Electrochemical DNA biosensor for screening of chlorinated benzene pollutants. Biosens Bioelectron 26:4040

19. Liang G, Li T, Li XH, Liu XH (2013) Electrochemical detection of the amino-substituted naphthalene compounds based on intercalative interaction with hairpin DNA by electrochemical impedance spectroscopy. Biosens Bioelectron 48:238

20. Wang GL, Zhou LY, Luo HQ, Li NB (2013) Electrochemical strategy for sensing DNA methylation and DNA methyltransferase activity. Anal Chim Acta 768:76

21. Luo L, Zhang Z, Ding Y, Deng D, Zhu X, Wang Z (2013) Labelfree electrochemical impedance genosensor based on 1aminopyrene/graphene hybrids. Nanoscale 5:5833

22. Li X, Shen L, Zhang D, Qi H, Gao Q, Ma F, Zhang C (2008) Electrochemical impedance spectroscopy for study of aptamerthrombin interfacial interactions. Biosens Bioelectron 23:1624

23. Bogomolova A, Komarova E, Reber K, Gerasimov T, Yavuz O, Bhatt S, Aldissi M (2009) Challenges of electrochemical impedance spectroscopy in protein biosensing. Anal Chem 81:3944

24. Chen Z, Li L, Zhao H, Guo L, Mu X (2011) Electrochemical impedance spectroscopy detection of lysozyme based on electrodeposited gold nanoparticles. Talanta 83:1501

25. Xiao Y, Pavlov V, Niazov T, Dishon A, Kotler M, Willner I (2004) Catalytic beacons for the detection of DNA and telomerase activity. J Am Chem Soc 126:7430

26. Pavlov V, Xiao Y, Gill R, Dishon A, Kotler M, Willner I (2004) Amplified chemiluminescence surface detection of DNA and telomerase activity using catalytic nucleic acid labels. Anal Chem 76: 2152

27. Kosman J, Juskowiak B (2011) Peroxidase-mimicking DNAzymes for biosensing applications: a review. Anal Chim Acta 707:7

28. Willner I, Shlyahovsky B, Zayats M, Willner B (2008) DNAzymes for sensing, nanobiotechnology and logic gate applications. Chem Soc Rev 37:1153

29. Zhou XH, Kong DM, Shen HX (2010) G-quadruplex-hemin DNAzyme-amplified colorimetric detection of $\mathrm{Ag}^{+}$ion. Anal Chim Acta 678:124

30. Liu X, Freeman R, Golub E, Willner I (2011) Chemiluminescence and chemiluminescence resonance energy transfer (CRET) aptamer sensors using catalytic hemin/G-quadruplexes. ACS Nano 5:7648

31. Won BY, Shin S, Fu RZ, Shin SC, Cho DY, Park HG (2011) A onestep electrochemical method for DNA detection that utilizes a peroxidase-mimicking DNAzyme amplified through PCR of target DNA. Biosens Bioelectron 30:73

32. Patolsky F, Lichtenstein A, Willner I (2003) Highly sensitive amplified electronic detection of DNA by biocatalyzed precipitation of an insoluble product onto electrodes. Chem Eur J 9:1137

33. Li XH, Zhou Y, Sutherland TC, Baker B, Lee JS, Kraatz HB (2005) Chip-based microelectrodes for detection of single-nucleotide mismatch. Anal Chem 77:5766

34. Liang G, Li XH, Liu XH (2013) Electrochemical detection of 9hydroxyfluorene based on the direct interaction with hairpin DNA. Analyst 138:1032

35. Orbach R, Willner B, Willner I (2015) Catalytic nucleic acids (DNAzymes) as functional units for logic gates and computing circuits: from basic principles to practical applications. Chem Commun. doi:10.1039/C1034CC09874A

36. Liu L, Liang Z, Li Y (2012) Label free, highly sensitive and selective recognition of small molecule using gold surface confined aptamers. Solid State Sci 14:1060

37. Yin H (2012) Amplified electrochemical microRNA biosensor using hemin-G-quadruplex complex as the sensing element. Analyst 27:7140 